\title{
Development of HPWH System Model, Using All Microchannel Heat Exchangers
}

Heat Pump Water Heater Using

Wrapped-Tank Microchannel Condenser

Coil for Charge Reduction - FY19 2rd

Quarter Milestone Report

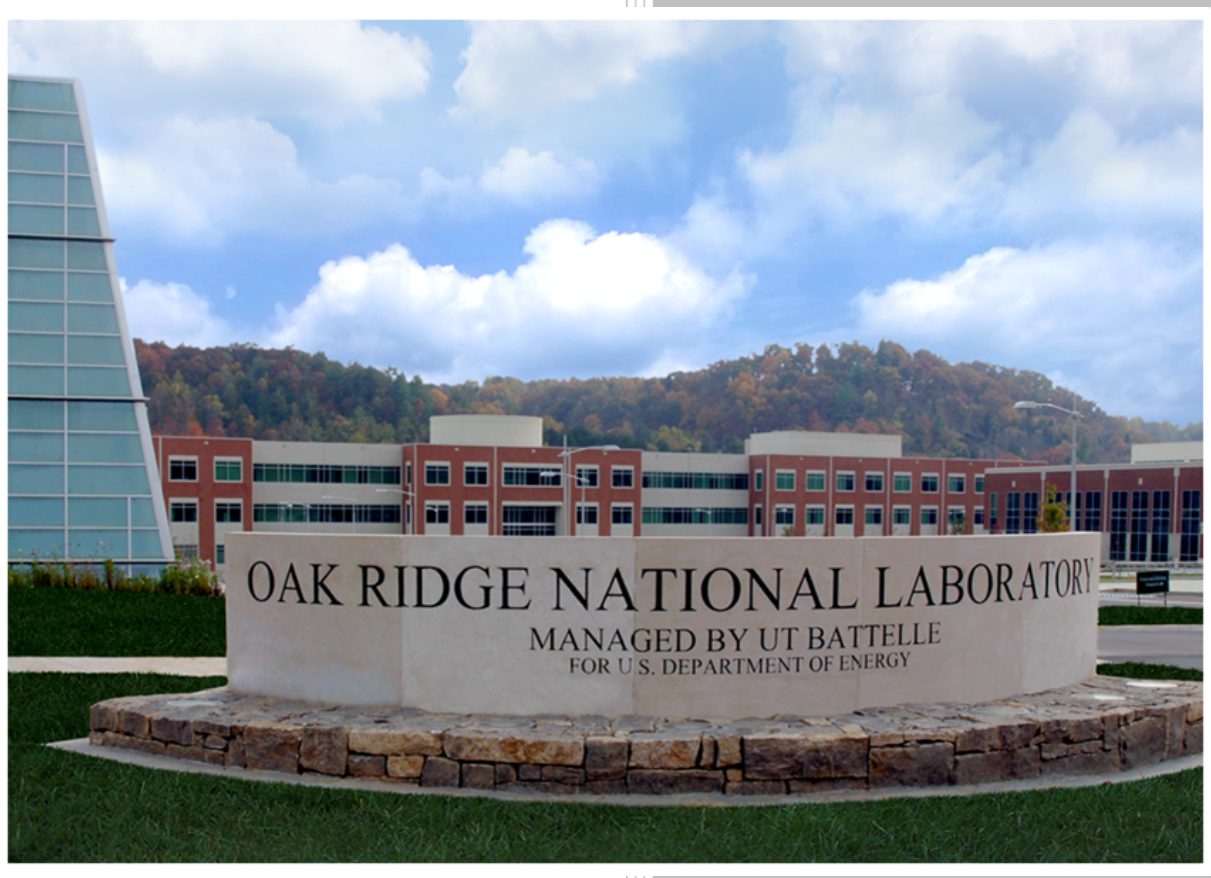

Approved for public release. Distribution is unlimited.

Bo Shen $03 / 31 / 2019$ 


\title{
DOCUMENT AVAILABILITY
}

Reports produced after January 1, 1996, are generally available free via US Department of Energy (DOE) SciTech Connect.

Website http://www.osti.gov/scitech/

Reports produced before January 1, 1996, may be purchased by members of the public from the following source:

\author{
National Technical Information Service \\ 5285 Port Royal Road \\ Springfield, VA 22161 \\ Telephone 703-605-6000 (1-800-553-6847) \\ TDD 703-487-4639 \\ Fax 703-605-6900 \\ E-mail info@ntis.gov \\ Website http://www.ntis.gov/help/ordermethods.aspx
}

Reports are available to DOE employees, DOE contractors, Energy Technology Data Exchange representatives, and International Nuclear Information System representatives from the following source:

Office of Scientific and Technical Information

PO Box 62

Oak Ridge, TN 37831

Telephone 865-576-8401

Fax 865-576-5728

E-mail reports@osti.gov

Website http://www.osti.gov/contact.html

This report was prepared as an account of work sponsored by an agency of the United States Government. Neither the United States Government nor any agency thereof, nor any of their employees, makes any warranty, express or implied, or assumes any legal liability or responsibility for the accuracy, completeness, or usefulness of any information, apparatus, product, or process disclosed, or represents that its use would not infringe privately owned rights. Reference herein to any specific commercial product, process, or service by trade name, trademark, manufacturer, or otherwise, does not necessarily constitute or imply its endorsement, recommendation, or favoring by the United States Government or any agency thereof. The views and opinions of authors expressed herein do not necessarily state or reflect those of the United States Government or any agency thereof. 


\title{
BTO Project 3.2.2.26 \\ FY19 $2^{\text {nd }}$ Quarter Milestone Report
}

\section{Development of HPWH System Model, Using All Microchannel Heat Exchangers}

\author{
Author \\ Bo Shen
}

Date: 03/31/2019

\author{
Prepared by \\ OAK RIDGE NATIONAL LABORATORY \\ Oak Ridge, TN 37831-6283 \\ managed by \\ UT-BATTELLE, LLC \\ for the \\ US DEPARTMENT OF ENERGY \\ under contract DE-AC05-00OR22725
}




\section{Development of HPWH System Model, Using All Microchannel Heat Exchangers (Regular Milestone)}

\section{Executive Summary}

In this report, 24-hour energy factor (EF) and first-hour draw rating (FHR) simulations were conducted on two heat pump water heater systems (HPWHs), one using a fin-and-tube evaporator and wrapped-tank condenser coil with D-shape tubes, and the other using a micro-channel evaporator and wrapped-tank condenser coil with microchannel tubes. Alternative refrigerants as drop-in replacements of R-134a were evaluated, including R-1234yf, R-1234ze(E), propane (R-290), R-450A and R-513A.

The results are summarized below:

1. Microchannel heat exchangers can decrease the system charge down to $30 \%$ relative to fin-and-tube evaporator and wrapped-tank D tubes.

2. Having the same contact surface area to the water tank and evaporator frontal flow area, the system using microchannel heat exchangers (MHXs) results in 5\% efficiency degradation. Due to the very small cross-sectional flow area of a microchannel tube, MHXs tend to have multiple parallel tubes to restrict the refrigerant pressure drop. The parallel pattern can't utilize the water temperature stratification as effectively as the D-shape tubes, which are arranged in one or two circuits and counter flow to the water stratification.

3. Refrigerant drop-in system simulations were conducted for R-1234yf, R-1234ze(E), propane, R450A and R513A in comparison to R-134a. Among the alternatives, propane has the largest volumetric capacity, which results in shortest HPWH run time and highest first-hour rating. Propane leads to the smallest energy factor because its largest volumetric capacity overloads the heat exchangers. R1234ze(E) has the smallest volumetric capacity, highest energy factor, but smallest first-hour rating. R1234yf, R-450A and R-513A achieve similar performance indices as R-134a.

4. Propane requires the least refrigerant mass (45\% relative to R-134a). If a wrapped-tank microchannel condenser and microchannel evaporator are used, the required system charge can be limited below 150 grams, which makes it feasible to use propane for domestic HPWH. 


\section{TABLE OF CONTENTS}

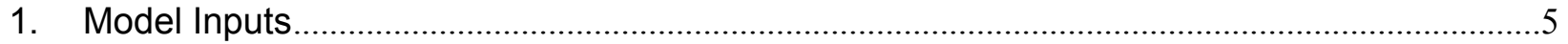

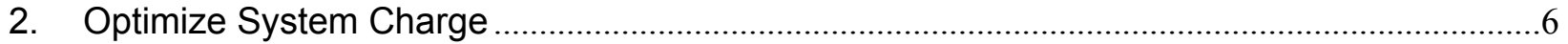

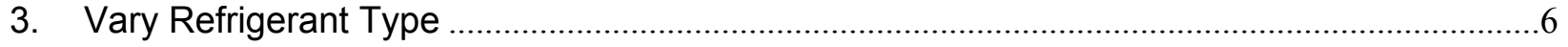

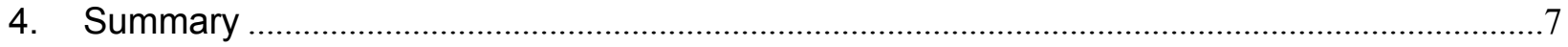




\section{List of Figures}

Figure 1: Compare energy factors (UEF) and system charge of the FTC and MHX HPWHs, with

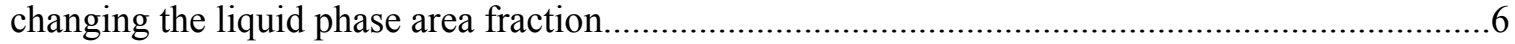

Figure 2: Performance indices of alternative refrigerants relative to R-134a in the FTC HPWH...............7

Figure 3: Performance indices of alternative refrigerants relative to R-134a in the MHX HPWH..............7

Figure 4: First-hour water draw ratings of alterative refrigerants........................................................ 


\section{LIST OF TABLES}

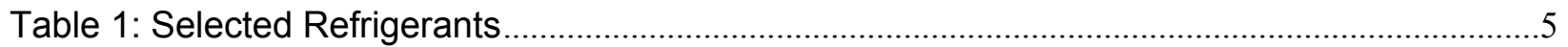

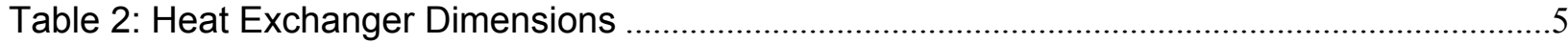




\section{Model Inputs}

The new micro-channel condenser and air-to-refrigerant micro-channel evaporator models were integrated to the DOE/ORNL Heat Pump Design Model (HPDM) for 24-hour energy factor and first-hour draw rating simulations. Since HPDM is hardware-based, a baseline HPWH was selected for geometry and dimension inputs. The baseline HPWH uses R-134a and a rotary compressor. The R-134a compressor map was provided by the manufacturer. For an alternative refrigerant dropped into the system, the compressor map was scaled assuming same volumetric and isentropic efficiencies at the same suction and discharge pressures.

Table 1 lists refrigerant types for this modeling study. It includes, the baseline refrigerant: R-134a, pure HFOs: R-1234yf and R-1234ze(E), two new HFO blends: R450A and R513A, and one natural refrigerant: propane (R-290). It should be noted that R-450A and R-513A are advocated as non-flammable replacements of R-134a. R-450A is a zeotropic refrigerant with small temperature glide $(<1 \mathrm{~K})$. R-513A is azeotropic with zero temperature glide.

Table 1: Selected Refrigerants

\begin{tabular}{|l|l|l|l|}
\hline Refrigerant & $\begin{array}{l}\text { Safety } \\
\text { Class }\end{array}$ & $\begin{array}{l}\text { Critical Temperature } \\
{\left[{ }^{\circ} \mathrm{C}\right]}\end{array}$ & $\begin{array}{l}\text { Critical Pressure } \\
{[\mathrm{kPa}]}\end{array}$ \\
\hline R-134a & A1 & 101.06 & 4059 \\
\hline Propane (R-290) & A3 & 96.7 & 4251 \\
\hline R-1234yf & A2L & 94.7 & 3382 \\
\hline R-1234ze(E) & A2L & 109.4 & 3635 \\
\hline $\begin{array}{l}\text { R-450A (R-134a/R-1234ze(E) [42/58 } \\
\text { Wt\%] })\end{array}$ & A1 & 104.5 & 3822 \\
\hline $\begin{array}{c}\text { R-513A (R-134a/R-1234yf [44/56 } \\
\text { Wt\%]) }\end{array}$ & A1 & 94.9 & 3648 \\
\hline
\end{tabular}

The baseline unit has a fin-tube evaporator and wrapped-tank condenser with $\mathrm{D}$ shape tubes. To conduct a comparative design study, the heat exchangers were replaced with a microchannel evaporator and wrapped-tank microchannel condenser. The wrapped-tank condensers have the same number of tubes, contact surface area and locations on the water tank. The evaporators have the same frontal flow area, using the same blower. The heat exchanger dimensions are given in Table 2.

Table 2: Heat Exchanger Dimensions

\begin{tabular}{llc}
\hline \multicolumn{2}{c}{ Wrapped-Tank Condenser } \\
\hline Type & D-shape tube & Microchannel tube \\
\hline Total Tube Number & 32 & 32 \\
\hline Number of parallel circuits & 2 & $\begin{array}{c}(24 \text { condenser+8 } \\
\text { subcooler) }\end{array}$ \\
\hline Tube/Port diameter [in] & 0.32 (outside diameter) & $\begin{array}{c}0.026\left(\text { hydraulic }^{2} \mathrm{~d}_{\mathrm{i}}\right) / 8 \\
\text { ports }^{1}\end{array}$ \\
\hline Tube Wrap Length [in] & 56.5 & 56.5 \\
\hline
\end{tabular}




\begin{tabular}{lll}
\hline & \multicolumn{2}{c}{ Air-to-Refrigerant Evaporator } \\
\hline Type & Fin-tube coil & Microchannel tube \\
\hline Total Tube Number & 28 & 36 \\
\hline Number of rows & 2 & 1 \\
\hline Number of parallel circuits & 2 & 36 parallel tubes \\
\hline Fin density (fins/ft) & 240 & 240 \\
\hline Frontal flow area $\left[\mathrm{ft}^{2}\right]$ & 1.85 & 1.85 \\
\hline Tube/Port diameter [in] & 0.375 (outside diameter) & $0.031\left(\right.$ hydraulic $\mathrm{d}_{\mathrm{i}}$ ) $/ 18$ \\
& & 19.0 \\
\hline Tube Length [in] & 19.0 & $150 / 13.0$ \\
\hline Air Flow $[\mathrm{cfm}] /$ Fan Power $[\mathrm{W}]$ &
\end{tabular}

1. the wrapped-tank microchannel tube has a width of 0.32 inch, i.e. the same as the outside diameter of the $\mathrm{D}$-shape tube. Each microchannel tube is divided to 8 rectangular ports in the condenser and 18 ports in the evaporator.

2. hydraulic $d_{i}$ is the inside hydraulic diameter of rectangular ports in microchannel tubes.

\section{Optimize System Charge}

Refrigerant charge optimization is required for developing any vapor compression products. Normal practice is to gradually increase the system charge and locate the best performance point. The charge optimization process can be tedious, while it is more time consuming for heat pump water heaters (HPWHs) as having to do 24-hour energy factor tests repeatedly. The model-based design makes it more efficient. In a HPWH using a TXV, addition of refrigerant charge mainly goes to the wrapped-tank condenser coil and increases the liquid phase area fraction, which lowers the condenser exit liquid temperature and increases the evaporator cooling capacity. However, adding charge causes higher compressor discharge pressure and temperature, which degrades the compressor efficiency. Figure 1 illustrates the predicated heat pump the unified energy factors (UEF) and total system charge of R-134a in the heat exchangers, as a function of the liquid phase area fraction. "FTC" represents the system having a fin-and-tube evaporator and wrapped-tank condenser with D-shape tubes, and "MHX" represents the system using all microchannel heat exchangers. With increasing the charge from 1.1 to $1.6 \mathrm{lbms}$ in the FTC system, the increase in UEF is noticeable. However, beyond the $1.6 \mathrm{lbms}$, the efficiency enhancement becomes flat. Use of MHXs effectively reduces the system charge. At the liquid phase area fraction of 0.4 and system charge of $0.42 \mathrm{lbm}$, and the UEF reaches optimum. It can be concluded: 1) MHXs can decrease the system charge down to $30 \%$ as compared to fin-and-tube evaporator and wrapped-tank D tubes; 2) when reaching the optimum charge, the MHX system requires a larger liquid phase area than the FTC system, i.e. 0.4 versus $0.2 . ; 3$ ) using the same contact surface area on the water tank and evaporator frontal flow area, the MHX system results in 5\% efficiency degradation. Due to the very small cross-sectional flow area of a microchannel tube, MHXs tend to have multiple parallel tubes to restrict the refrigerant pressure drop. The parallel tube pattern can't utilize the water temperature stratification as effectively as the D-shape tubes which can be arranged in one or two circuits, counter flow to the water stratification. Consequently, the heat capacity distribution among the microchannel tubes is not uniform. 


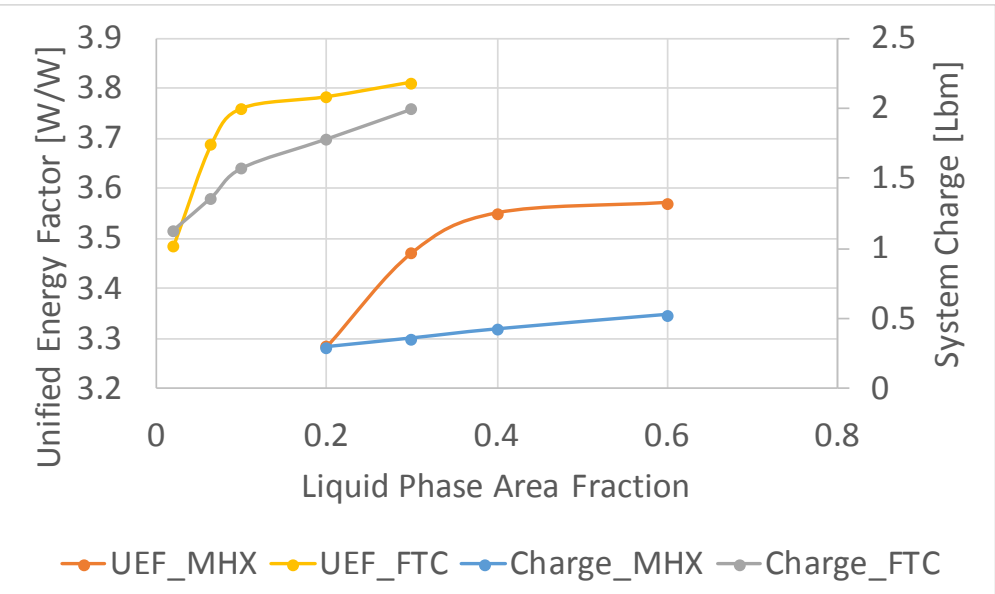

Figure 1: Compare energy factors (UEF) and system charge of the FTC and MHX HPWHs, with changing the liquid phase area fraction.

\section{Vary Refrigerant Type}

R-134a is the most used refrigerant for HPWHs. However, its global warming potential (GWP) is very high, i.e. 1430. R-134a will be phased out soon. The candidates of direct drop-in replacement, i.e. using the same compressor and heat exchangers, include R-1234yf (GWP of 4), R-1234ze(E) (GWP of 2) and propane (R290, GWP of 3), R-450A (GWP of 605), R-513A (GWP of 631).

Assuming the same volumetric and isentropic efficiencies at the same suction and discharge pressures when varying the refrigerant, 24-hour UEF simulations were conducted for these refrigerants. In order to compare the system charges, it is assumed that the required charge leads to $20 \%$ liquid phase ratio for each individual refrigerant in the FTC HPWH; and 40\% liquid phase ratio in the MHX HPWH.

Figures 2 and 3 compare the unified energy factors (UEF), heat pump run time in a 24-hour run, and required system charges, relative to the baseline R-134a, for the FTC system and MHX system respectively. Comparing Figure 2 and Figure 3, one can see that the performance ratios among the alternative refrigerants are identical, regardless of the choices of heat exchangers. R-1234ze(E) has the longest running time, indicating that the refrigerant has the smallest volumetric capacity. With reducing the capacity, the heat exchangers are unloaded, consequently, R-1234ze(E) achieves the highest UEF. R-290 results in the shortest runtime because of its highest volumetric capacity, which degrades its efficiency. R-1234yf's performance is slightly worse than R-134a. R-290 requires 55\% less charge, due to its small molecular weight. In the MHX system, the calculated R-290 mass is 80 grams, which is lower than the 150 grams charge limit for safely using propane at home. All other alternative refrigerants require similar refrigerant system charge. R-450A and R-513A results in similar performance as R-134a, with R-450A being slightly more efficient.
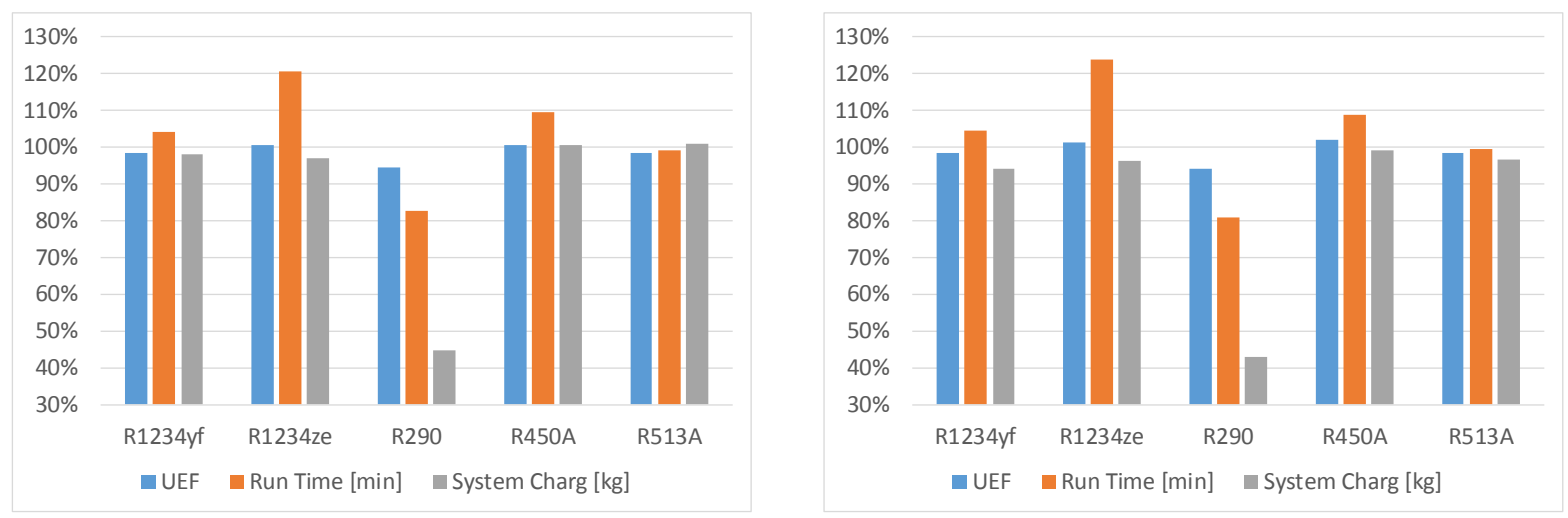


\section{Figure 2: Performance indices of alternative refrigerants relative to $\mathrm{R}-134 \mathrm{a}$ in the FTC HPWH.}

\section{Figure 3: Performance indices of alternative refrigerants relative to $\mathrm{R}-134 \mathrm{a}$ in the $\mathrm{MHX}$ HPWH.}

Figure 4 gives simulated first-hour water draw ratings (FHRs) of the various refrigerants. In general, the FHRs don't differ much because they are dominated by the top resistance heater $(5 \mathrm{~kW})$. On the other hand, the draws (gallons) indicate the refrigerant volumetric capacities. R-290 leads to largest water draw, while other alternatives result in 5\% to 10\% lower FHRs than R-134a.

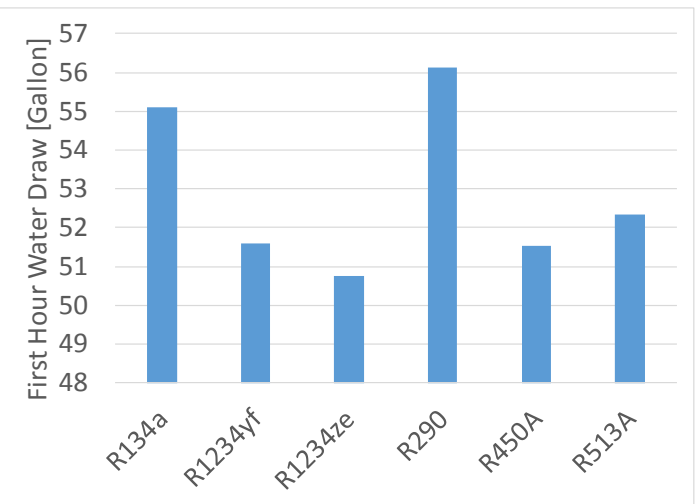

Figure 4: First-hour water draw ratings of alterative refrigerants

\section{Summary}

It can be concluded:

1. Microchannel heat exchangers can decrease the system charge down to $30 \%$ relative to fin-and-tube evaporator and wrapped-tank D tubes.

2. Having the same contact surface area to the water tank and evaporator frontal flow area, the MHX system results in 5\% efficiency degradation. Due to the very small cross-sectional flow area of a microchannel tube, MHXs tend to have multiple parallel tubes to restrict the refrigerant pressure drop. The parallel pattern can't utilize the water temperature stratification as effectively as the D-shape tubes, which are arranged in one or two circuits and counter flow to the water stratification.

3. Refrigerant drop-in system simulations were conducted for R-1234yf, R-1234ze(E), propane, R450A and $\mathrm{R} 513 \mathrm{~A}$ in comparison to R-134a. Among the alternatives, propane has the largest volumetric capacity, which results shortest HPWH run time and highest first-hour rating. Propane leads to the smallest energy factor because its largest volumetric capacity overloading the heat exchangers. R$1234 z e(E)$ has the smallest volumetric capacity, highest energy factor, but smallest first-hour rating. R1234yf, R-450A and R-513A achieve similar performance as R-134a.

4. Propane requires the least refrigerant mass (45\% relative to R-134a). If a wrapped-tank microchannel condenser and microchannel evaporator are used, the required system charge can be limited below 150 grams, which makes it feasible to use propane for domestic HPWH. 